\title{
PERIODICAL CERKNICA LAKE IN FRISCHLIN'S (1547-1590) WORK
}

\author{
PRESIHAJOČE CERKNIŠKO JEZERO V FRISCHLINOVEM \\ (1547-1590) DELU
}

\author{
Stanislav JUŽNIČ
}

\begin{abstract}
UDC: 52(091):929Frischlin N Stanislav Južnič: Periodical Cerknica Lake in Frischlin's (1547-1590) work

Ljubljana rector Frischlin's work about Cerknica Lake (15821584) is described. Frischlin's connections with other protestant and catholic researchers are put in the limelight. Frischlin wrote his most important astronomical work De astronomicae artis at Ljubljana. It was the first world-wide recognised scientific work produced at the area of modern Slovenia. Valvasor published comparatively long description of Frischlin work at Ljubljana with the special concern put on Frischilin's poetry devoted to the secrets of periodical Cerknica Lake. The speleologist Urbas partially translated Frischlin ode nearly two centuries after Valvasor's publication. This pioneering discussion is devoted to Frischlin's important contribution to 16th century subterranean karst research.

Keywords: Ljubljana, Nikodem Frischlin, Janez Vajkard Valvasor, Anton Urbas, History of Slovenian Karst Research, Cerknica Lake.
\end{abstract}

Izvleček

UDK: 52(091):929Frischlin N. Stanislav Južnič: Presihajoče Cerkniško jezero v Frischlinovem (1547-1590) delu

Opisana je doslej manj znana pesnitev ljubljanskega rektorja Frischlina o Cerkniškem jezeru (1582-1584). Njegova prepričanja so primerjana $\mathrm{z}$ drugimi protestantskimi in katoliškimi učenjaki. Frischlin je v Ljubljani sestavil vplivno astronomsko delo, najbolj zgodnjo knjigo tako visoke ravni nastalo v naših krajih. Prvi med zgodovinarji podrobneje opisujemo razmeroma dolgo Valvasorjevo predstavitev Frischlina s poudarkom na njegovi pesnitvi v slavo čudesom Cerkniškega jezera. Delni prevod Frischlinove pesnitve je oskrbel speleolog Urbas.

Ključne besede: Ljubljana, Nikodem Frischlin, Janez Vajkard Valvasor, Anton Urbas, zgodovina raziskovanja slovenskega krasa, Cerkniško jezero.

\section{INTRODUCTION}

Frischlin was the first world-wide known Ljubljanian researcher of subterranean flows of Cerknica Lake. He worked at Ljubljana just a little over two years, but he certainly marked the Carniolan capital at the scientific and cultural map of Europe. Frischlin is famous today for his Latin poetry which includes his Karst research and, last but not least, his early Cerknica Lake Subterranean description.
Frischlin was important for the Ljubljana sciences of his era as much as Kepler was at the same time at Graz. Both worked at the schools of the similar types, the rector Frischlin certainly at the somewhat higher position. Frischlin's Ljubljana school was abolished fourteen years after he left, pushing his Carniola works somewhat at the oblivion. But he is certainly known well enough that we could bring his subterranean research in the limelight at the $460^{\text {th }}$ anniversary of his birth.

\footnotetext{
${ }^{1}$ Univerza v Oklahomi, Norman, Fara 2, SI-1336 Kostel, stanislav.juznic-1@ou.edu, stanislav.juznic@fmf.uni-lj.si Received/Prejeto: 27.03.2008
} 


\section{STUDENT FRISCHLIN}

The family Frischlin (Friuschlin) has its roots at Thüringian Diessenhofen. His grandfather moved to Württenberg, settled at Balingen, and worked at the court of duke Ulrich. Nikodem's father Jakob Frischlin $\left({ }^{\star} 1522 ; \dagger 1603\right)$ became a natural philosopher, theologian, and deacon there. Nikodem Frischlin (* September 22, 1547 Balingen; $\dagger$ November 29, 1590 Hohenurach at Württenberg) was his oldest son (Froeschlin 1979, 1). At November 12, 1562 Nikodem matriculated at the University Tübingen as »Nicodemus Fröschlin Balingensis«, a year after Primož Trubar moved to nearby Urach where Frischlin later sadly finished his days.

At August 7, 1567 Frischlin became Master of Arts as the best of Crusius' twelve students. Frischlin's later enemy Martin Crusius ${ }^{\star} 1526$ Greben 3 miles from Bamberg), a son of the Protestant preacher, joined Tübingen University at 1559.

Frischlin studied philology with his friend Dietrich Schnepfuss $(* 1525 ; \dagger 1586)$, who lectured as the third full professor of theology between the years 1556-1586. The father of Schnepfuss' wife Barbara Brenz and the father of Frischlin's wife Margaretha Brenz († 1599) were cousins (Röckelein \& Bumiller 1990, 58).

Frischlin studied philosophy with the botanist and the first full professor of the Medical Faculty Leonard Fuchs, who taught between 1535 and 1566. Frischlin learned Aristotle's physics with his later enemy Georg Liebler $\left.{ }^{*} 1524 ; \dagger 1600\right)$ who taught as professor between the years 1552-1594. Before Apian, Johann Schenber lectured on mathematics and astronomy between the years 1544-1570 and taught Frischlin's as well. Schenber later became the third full professor at the Medical Faculty where he replaced Jacob Degen called Schegk ${ }^{*} 1511$ "Schorndorffensis"; $\dagger$ 1587) who taught at Medicine Faculty between the years 1553-1577. Liebler's and other lec-

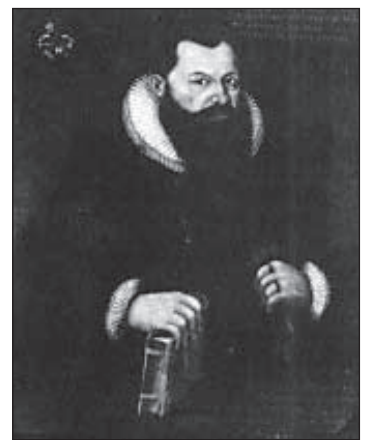

Fig. 1: Thirty years old Frischlin, just before he arrived to Ljubljana.

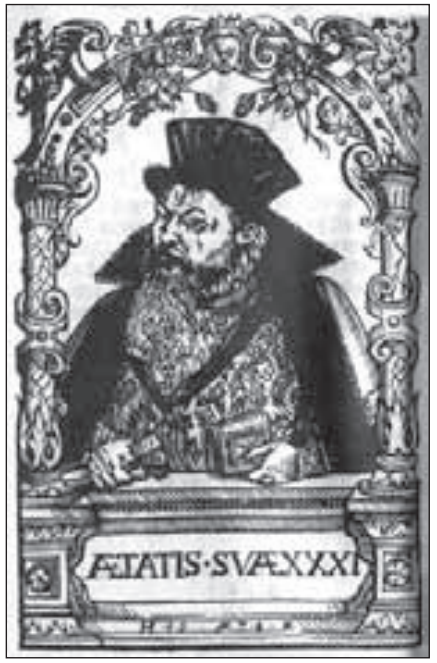

Fig. 2: Frischlin's bust at Tübingen professors gallery erased in 1634, nearly half of the century after his death.

tures helped Frischlin to learn Aristotle's and more modern opinions about the subterranean water currents.

Frischlin began to teach as the second professor repeating Greek language lectures at Tübingen. In October 1568 he became the professor of Vergil's poetry. Between April 2, 1567 and June 16, 1582 he was an extraordinary professor of poetry and history at the Tübingen Faculty of Arts (Röckelein \& Bumiller 1990, 44-45, 47, 58, 135; Strauss 1856, 18, 29). At November 2 and 3, 1568 he celebrated his wedding with Margaret, a daughter of Anne $(\dagger 1592)$ and Hans Brenz ( $† 1574 / 1578)$, court master of the Württenberg duke at the monastery Reuthin near Wildberg. At November 11, 1571 Frischlin's first son Johann Jakob was born. His godfather was Martin Crusius who was still Frischlin's friend at that time.

\section{PROFESSOR FRISCHLIN}

Peter Apian's $\left({ }^{*} 1495\right.$ Leising; $\left.\dagger 1552\right)$ son, the Protestant Philipp Apian (* 1531 Ingolstadt), had some religious troubles at Ingolstadt University. On October 4, 1569 he left for Tübingen and next year he began lecturing on astronomy and geometry (Hermelink 1976, 50 (172/63); Strauss 1856, 39; Granada 2007, 123). He kept his chair until 1584 when he was eventually able to return to Ingolstadt. During Apian's absence Frischlin continued his lectures on sphere (doctrina sphaerica) in 1569-1570 and 1571-1572 (Methuen 1998, 118).
Among Frischlin's students was later Kepler's teacher Maestlin.

In 1571 Tübingen University was closed to prevent the plague spreading. For seven years Frischlin led three-hour philosophical disputations with the bachelor degree candidates. He accomplished the encyclopedia of physics, astronomy and other materials including subterranean theories for his students. In autumn 1574 Frischlin examined as much as thirty-eight candidates with last questions about astronomy and Earth theories. In June 
1572 Schegk declined the offer for medicine and Aristotle's Organon lecturing chair and Frischlin got his post. Private docent Giordano Bruno was among Frischlin's collaborators for a while (Strauss 1856, 40, 71, 414).

On his way to the Speier Reichstag Frischlin visited Strasbourg for the first time in 1570. In 1574 he was there again writing a poem about the new Dasypodius' astronomical clock of Strasbourg cathedral which also showed days at week and month, Lunar phases, positions of Sun and Planets (Frischlin 1575; Weichenhan 2004, 532; Röckelein \& Bumiller 1990, 7, 135-136). Frischlin consulted the Strasbourg professor of mathematics Conrad Dasypodius (Hasenfuss, Rauchfuss, Rauhfuss, ${ }^{\star} 1532$ Swiss Frauenfeld; $\uparrow 1600$ Strasbourg) (Poggendorff 18631898, 806; Thorndike 1941-1958, 6: 88).

\section{FRISCHLIN'S LJUBLJANA}

In November 1576 Frischlin was offered a rector's chair at Graz where Kepler later taught. Frischlin's supervisor duke of Württenberg eventually declined the offer (Röckelein \& Bumiller 1990, 136). Frischlin had some problems because he drank a lot and he was eventually unable to hold his tongue. He was more successful at the imperial court. In 1575 Maximilian II crowned him as poet laureates after Frischlin recited his new comedy Rebecca at Regensburg. At October 12, 1576 Emperor Rudolf II at Regensburg gave Frischlin a diploma as poet laureates and in 1577 and 1580 he added a diploma comes palatinus (Pfalzgraf) (Strauss 1856, 94, 98; Kidrič 1925-1932, 190; Röckelein \& Bumiller 1990, 52, 136; Hermelink 1976, 432 (158, No. 42)).

In Tübingen Frischlin was at informal house arrest and hardly waited for a post far enough from his enemies. He seems to be quite happy when Johann Pianer (Ivan Piano) offered him Ljubljana rector's chair on $\mathrm{Hi}$ eronymus Megiser's ( ${ }^{\star}$ 1554/55 Stuttgart; † 1619 Linz) recommendations (Strauss 1856, 247; Elze 1899, 139). Megiser was Frischlin's best student at Tübingen.

At April 3, 1582 Dr. Jakob Andrea of Tübingen and Primož Trubar of Derendigen searched for the replacement for the retired Ljubljana Estates General School rector Adam Bohorič. At that time Frischlin's conflict with Frank knights was not widely known, especially not in Ljubljana. Frischlin's Oratio de vita rustica offended many nobles (Frischlin 1580). He poetically praised peasant's life at those hard times of unrest and rebellions. At May 12, 1582 Duke of Württenberg certainly wrote with a due praise about Frischlin's work, but the quarrel was never settled down (Elze 1899, 136; Röckelein \& Bumiller 1990, 90).

At June 24, 1582 Frischlin sailed the Danube River casting the anchor at Vienna. He continued his journey to Graz and Ljubljana on horseback. During early June heat he finally reached Ljubljana still without his family and on August 1, 1582 he occupied the rector's chair at Estates General School. Frischlin received a yearly salary of $450 \mathrm{fl}$ with a half of school fees money included. The nobles gave him deer and Estates General added a taller per day for the good Vipava wine. Ljubljana salary was comparatively high as Frischlin received only 120 gld at Tübingen in 1577 and even Apian (220 gld) and Andreae (280 gld) did not get much more, although they certainly had free wine and corn. Even Frischlin's Ljubljana predecessor Adam Bohorič accomplished just 140 per annum (Strauss 1856, 254; Röckelein \& Bumiller 1990, 69, 138).

During his Ljubljana times Frischlin published two Latin textbooks at Venice, but he was eventually not allowed to use them at the classroom (Janko 1996, 172; Kidrič 1925-1932, 190). At August 24, 1582 Estates General accepted Frischlin and Spindler's proposition to hire Lorenz Meiderlin (Meuderlin) of Württenberg as the vice-rector and Latin lecturer at fourth class, although he was unable to use Slovenian language. Meiderlin stayed at Ljubljana between 1582 and 1600 as präceptor with $100 \mathrm{fl}$ per year (Elze 1877, 13). Frischlin received the right to propose Meiderlin already at his own contract and Meiderlin probably helped Frischlin's Cerknica Lake Karst research on his way from Ljubljana to Venice.

Frischlin also hired other hands for his Ljubljana school. Simon Bruno lectured Julius Cesar's Latin text at his third class lectures receiving annual salary of $90 \mathrm{fl}$. Sebastian Semnider taught $2^{\text {nd }}$ class, sang, and conducted German sacred songs and Slovenian poems of Mathias Vanizianer at the church. Semnider received $40 \mathrm{fl}$ and additional $112 \mathrm{fl}$ per annum. Luka Selenz lectured at the lowest 1st class and also taught calligraphy for $85 \mathrm{fl}$ per annum (Kidrič 1925-1932, 191; Strauss 1856, 262; Elze 1899, 139). In 1583 Frischlin had twenty-two students at $3^{\text {rd }}$ class, nine at $4^{\text {th }}$ class, and six at $5^{\text {th }}$ class (Röckelein \& Bumiller 1990, 111).

Upon arrival Frischlin shared the Swabian Krištof Spindler's (* 1546 Göppingen; 1591 Ljubljana) housing facilities. On suggestion of Primož Trubar (1569) Spindler was already thirteen years the first preacher (superintendant) at Ljubljana after the early death of Sebastijan 


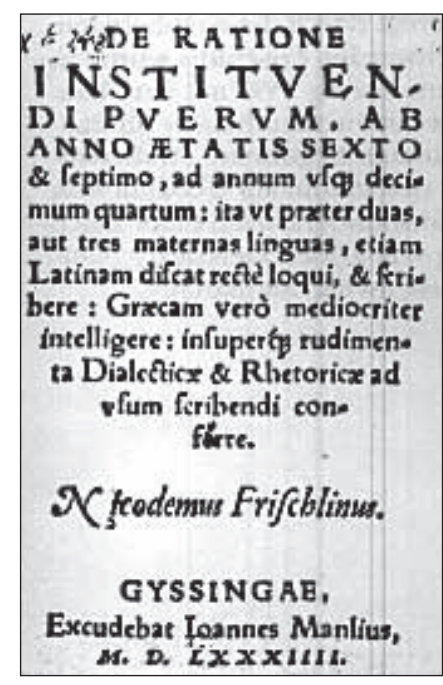

Fig. 3: September 13, 1583

Frischlin's book dedicated

to Baron Jurij Khisl ( +1605

Polhov Gradec), just after

Fischlin's friend Megiser

finished tutoring Khisl's

children at Fužine castle

(NUK).
Krelj $(* 1538 ; \dagger 1567)$, although Spindler was unable to use Slovenian language (Hermelink 1976, 439 (160/12, 217/125)). Spindler was also majordomo of Herbard VIII Auersperg. After the brave death of his patron Spindler wrote an elegy which the Governor General Count Volf Engelbert Auersperg kept at his famous library (Južnič 2007a, 310).

Frischlin later lived at Ljubljana house called »Poscherl« (Elze 1899, 138). Frischlin brought to Ljubljana at least six of his sixteen children. His daughter was born at Ljubljana but she also died there. His wife Margaret Frischlin was not satisfied at Ljubljana because she did not know the local language and complained about the bad air and water.

\section{CERKNICA LAKE POEM}

During his stay in Ljubljana (1582-1584), Frischlin wrote a Latin poem about the Cerknica Lake and Valvasor later reprinted it (Valvasor 1689, 2 (7): 450). Valvasor eventually borrowed some Frischlin's century old ideas. The caver Anton Urbas translated a part of Frischlin's ode into German three centuries after Frischlin wrote it (Gams 2003, 13, 485; Urbas 1879, 25). Urbas' translation eventually proved how good Frischlin was even if he used later abandoned Latin lingua franca. Frischlin's description of Cerknica Lake had lasting scientific and artistic value deserving to be engraved at the frequently visited karst region of the Cerknica Lake neighborhood.

Urbas translated four and below them additional fourteen verses of altogether thirty-four Frischlin's verses published at Valvasor's Ehre. Therefore Urbas selected about the half of all poem. Valvasor dedicated a whole eight pages paragraph to Frischlin's rectorship at Ljubljana (Valvasor 1689, 2 (7): 445-452) carefully describing his Ljubljana and Cerknica Lake affairs. Valvasor reprinted Frischlin's correspondence with the Carniola Estates General at their mutual farewell in August 1584 with Frischlin's letter (August 9, 1585) and writings of the Carniolan Viceroy Wolfgang Count Thurn at August 1, 1584 (Valvasor 1689, 2 (7): 448). Frischlin's Cerknica Lake ode was connected with otherwise unknown local man Gašper Godesch (De Lacu Circuito ad Gasparum Godescheum Cirknitarum carmen) whose family name Godeša is still pretty common at the Cerknica area.

At the opening verse not translated by Urbas, Frischlin as a man of the world compared the Cerknica Lake secrets with a famous dilemma of Nile River and its sources. Frischlin also discussed Nile at his final verses which Urbas similarly did not consider important enough for karst research to take the trouble of translation. Urbas did not even mention Nile in his article. But Urbas certainly translated those karst related parts of the Frischlin's poem which described the changing of the water level at the lake, subterranean currents, and fishing during flood periods.

Frischlin beautifully pictured earthy paradise of the famous Cerknica Lake surrounded with mountains. The Lake flowed into subterranean and later reappeared again. The "spirit" of water lifted up from the karst ground and later returns back. The ground full of holes swamped the Lake waves into subterranean region which was pretty hard to describe at Frischlin's time because of the lack of any experimental relevant evidence. But Frischlin certainly did his job well.

At his Oratio de vita rustica published two years before his arrival to Ljubljana Frischlin showed deep interest and sympathy for the peasant way of life. He eventually liked farmer's company and described in detail the agricultural economy at the dried Cerknica Lake bottom. The earth totally absorbed the water to make place for the green meadows. They ploughed up the land at the same way the Egyptians did after the Nile floods. Peasants seeded their pre-Columbian seeds including chickpea, millet, pea, broad beans, and wheat so that cereals yellowed the land. Peasants worked with their hoes until the autumn brings the harvest time. After the freeze the flood waves raise from the deep subterranean karst. The water returns through the siphons and files the val- 
ley again. The flood brings the river fishes. Frischlin was the first to report about miraculously whirling fishes and even ducks. His colorful Renaissance story about the flying ducks ready for the cooking proved to be especially important because Valvasor and other later authors repeated it for centuries.

Frischlin also added the tales about the easy winter Cerknica Lake fishing. The able fishermen sailed through the former meadows and hunters searched the migratory birds. They use their mattock to beat the bundles of frozen fish stuck at the ice.

Frischlin was apparently an eyewitness, probably visiting the Lake in September 1583. Frischlin became familiar with winter Cerknica circumstances witnessing fishing or even legendary flying ducks during the sudden flood. Valvasor certainly believed at Frischlin's stories about ducks. Frischlin's idea about underground siphons (siphonibus) proved to be even more important. It became a part of Valvasor's price-winning paper sent to the Royal Society of London, eventually without mentioning Frischlin's contribution.

Frischlin was certainly the very best Latin poet of his era and he could use the word siphonibus even to describe the syringe or simple pipe and not just at the modern siphon sense which includes intermediate vacuum. But Valvasor's Latin was eventually far inferior and did not exceed the middle school level too much. Therefore Valvasor was probably unable to understand clearly all the hints of Frischlin's Latin poetry. In 1669 Edward Brown (* 1642; $\dagger 1708)$ eventually used the Frischlin's siphon hypothesis to describe his hidden reservoir lakes beneath the Javornik Mountains. Brown's siphons were connecting the visible Cerknica Lake and supposed subterranian Lake.

At the same manner Valvasor and Steinberg thought about the unending row of siphons under the Javorniki. Gruber was eventually the first to publish the sound critique of the Cerknica Lake siphon theory. He didn't accept Steinberg's description of Cerknica Lake as a system of mutually connected siphons. Gruber was among the first to be aware of the water level static balancing the influx of rain and flows of the rivers towards the seas (Gruber 1795, 4). His description of the Cerknica Lake and Planina Polje hydrology far surpassed his predecessors. Frischlin certainly did not use such ideas two centuries before Gruber's more mathematical treatment. Frischlin's and also later Kircher's were more concerned with hardly determinable amounts of the subterranean water flows at the same manner we today discus the dark mater of the cosmos without having reliable guesses about its quantity (Južnič 2007b, 505).

Frischlin imagined subterranean tubes at the karst ground full of holes with the water flowing through them to fill the lake, and later to empty it again. Frischlin described the Cerknica Lake very son after the first known topological contribution of the Viennese physician Georg Werner (Werner 1551; Valvasor 1689; Habe \& Kranjc 1981, 14-16). Today we certainly read Frischlin's poem as unscientific because the modern scientific language is divorced from any kind of poetry. In spite of that even the 18th century scientists did not consider Bošković's poems as unscientific. Educated people still praised verses much higher compared with the simple prose. But our present view is certainly different as scientific language developed into lingua franca which should not be translated into the poetry any more.

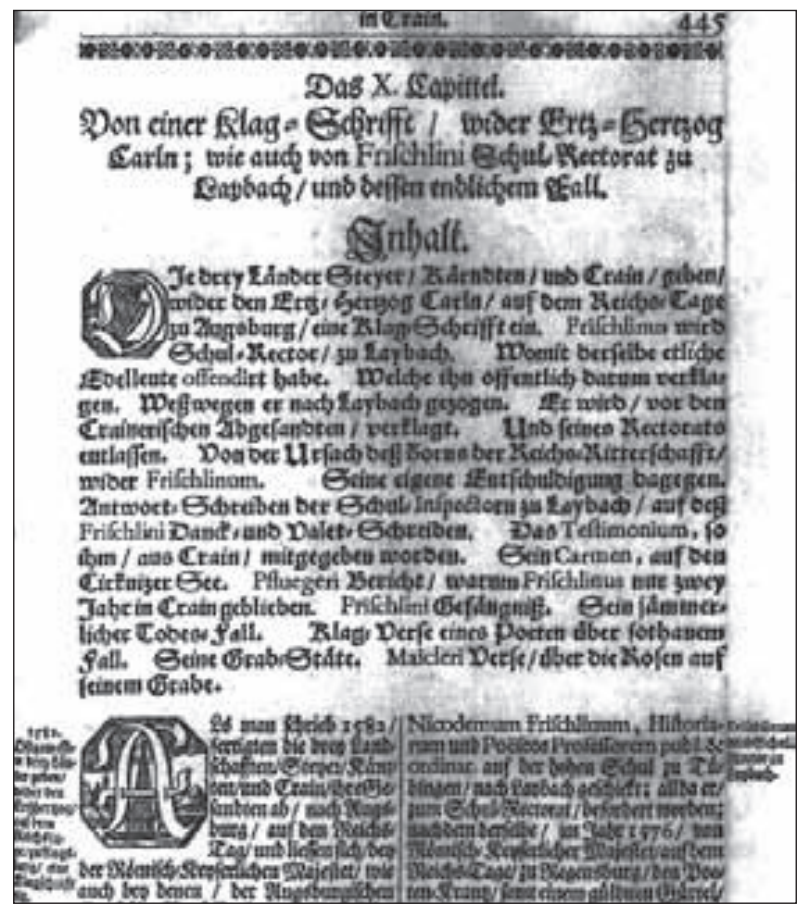

Fig. 4: Title page of Valvasor's eight page paragraph describing Frischlin's rectorate at Ljubljana (Valvasor 1689, 2: 245).

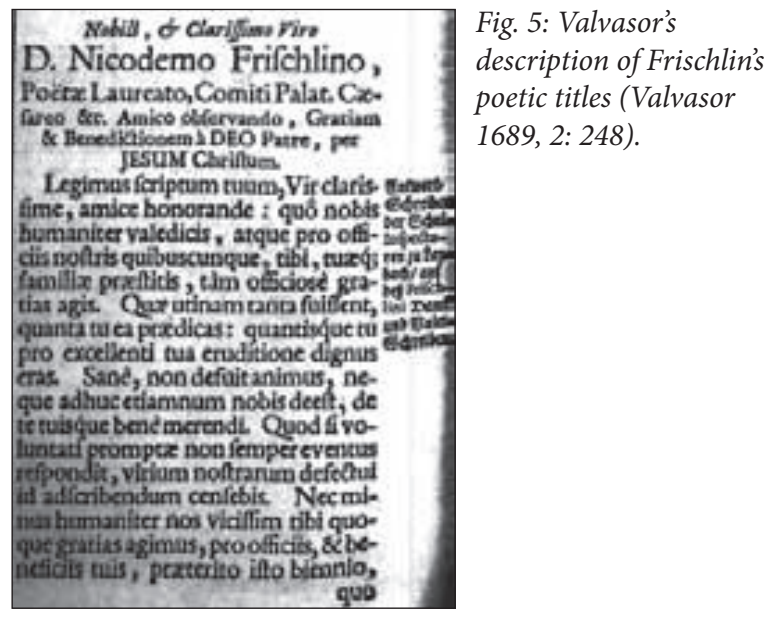




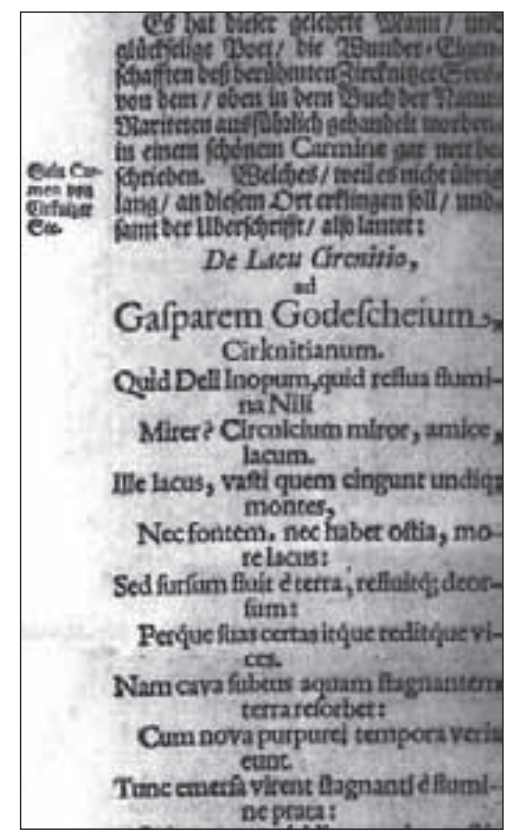

Frischlin personally examined Cerknica Lake during his September 1583 journey to Venice and Padova and also enjoyed his vine-testing travels to the peasant communities and pubs around Cerknica Lake. Otherwise Frischlin did not have much time to spend on karst Lake poetry (Valvasor 1689, 2: 250).

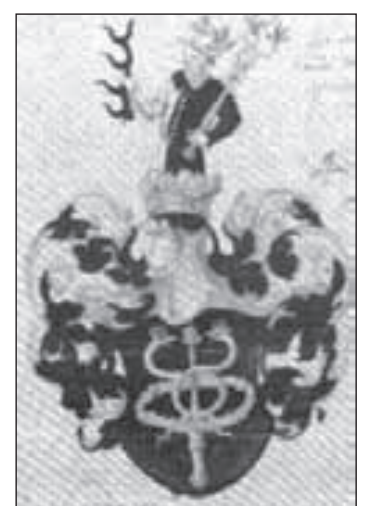

Fig. 7: Frischlin's coat of arms (Röckelein \& Bumiller 1990).

research and travel besides his quite time absorbing rector job. He put arithmetic with exact sciences, at third and later classes of his new 1584 school program (Vidmar 2000, 10, 15, 16, 17). Frischlin himself probably also gave some lectures even if he was a rector and certainly recited the verses of his Cerknica Lake and karst poem to amuse the students and other Ljubljana citizens. Frischlin was certainly best educated Ljubljanian of his era and his contributions were surely welcomed although not everybody understood Frischlin scientific level. Frischlin himself certainly had a very favorable opinion about the educational level of Carniolan nobility especially considering their language abilities (Janko 1996, 170).

\section{FRISCHLIN'S TRANSLATOR ANTON URBAS}

Valvasor's description of Protestant affairs in Inner Austria covered eight paragraphs including Frischlin's one. They were among the best Valvasor ever published, also because Valvasor used acts of Estates General and Imperial decrees at their original form kept at the Archives of the Estates General. Even more: at those paragraphs Valvasor showed some sarcasm towards the winning catholic party. Valvasor presented an unconcealed sympathy to Frischlin and his fellow Protestants, even if that kind of political opinion could bring him some troubles so soon after counterreformation won the battle in Carniola. At the other side, some influence of Valvasor's principal Protestant collaborator Erasmus Francisci (* $1627 \mathrm{Nu}$ remberg; $\dagger$ 1694) could be felt (Reisp 1983, 228).

Valvasor's publication of Frischlin's Cerknica Lake poem was somewhat hidden until one of the most important new age Slovenian speleologist Urbas ( ${ }^{*}$ September 13, 1822 Idrija; $†$ September 22, 1899 Ljubljana) partially translated it. Urbas was a son of Idrija mine official connected with the other famous Idrija speleologist, Dragotin (Karl) Dežman (* January 3, 1821 Idrija; † March 11, 1889 Ljubljana), who was just few months older. Dežman was a son of the Idrija law court actuary. He eventually lost his father very early and moved to Ljubljana already in 1824 , but certainly knew Urbas very well.

Urbas studied theology at Ljubljana and was ordained there in 1844. He served as curator at Kovorje, Smlednik, Planina near Rakek, and until 1850 at Sostro near Ljubljana. He got a beneficiate at Gorčica near Domžale (1851-1859), became priest at Zagorje (18601873) and at Dobovec (1874-1876), and finally Ljubljana Cathedral priest and canon.

In autumn 1848 the Planina priest Urbas used his influence to organize and lead the very first expedition at Postojna Cave. As Dežman, Urbas researched Vranja and other caves. Urbas described them at very influential publications. He and his collaborators reached the confluence of the rivers Pivka and Rak and found some Proteus at Pivka River branch. A year later Adolph von Schmidl $*^{*} 1802$; $\left.† 1863\right)$ used Urbas achievements for his own work (Habe \& Kranjc 1981, 35, Savnik 1982, 302; 3: 224-225; Urbas 1849; Schmidl 1850).

Just like Frischlin, Urbas was also interested at other aspects of physical word besides karst. Frischlin wrote 


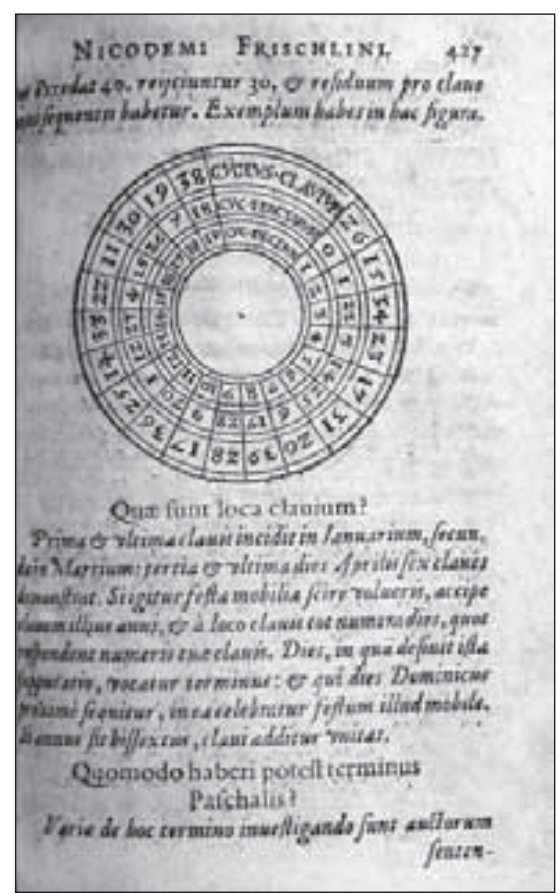

Fig. 8: Frischlin counts the New Year and Easter (Pasch) dates (Frischlin 1586, 427).

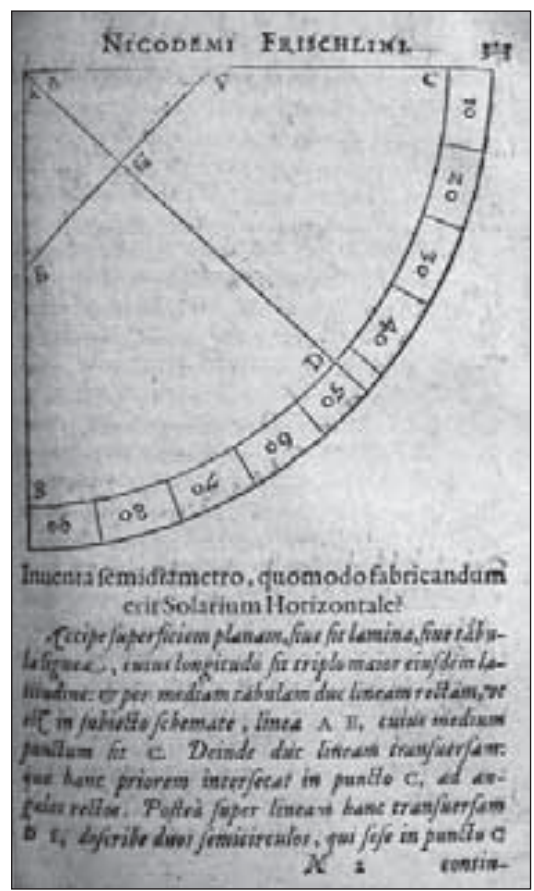

Fig. 9: Frischlin explains horizontal gnomon building (Frischlin 1586, 323).

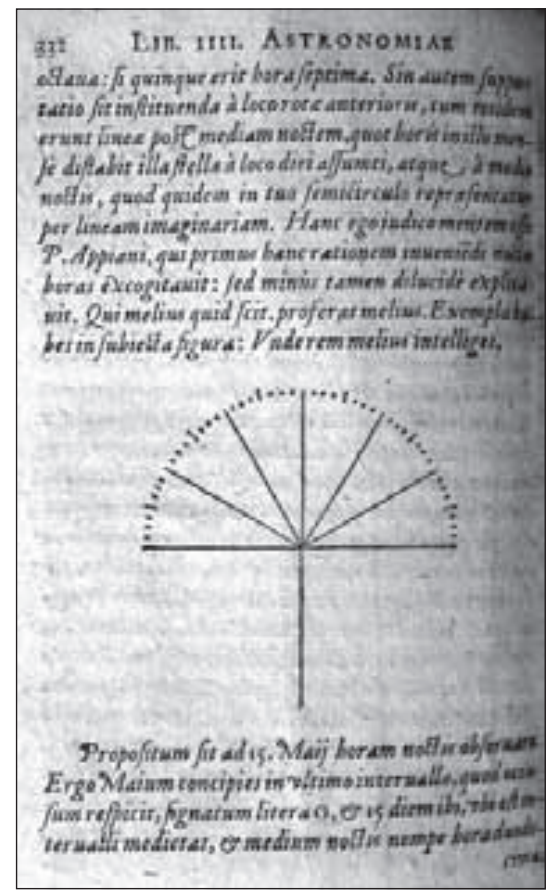

Fig. 10: Frischlin's drawing of P. Apian's equipment for night time measurements (Frischlin 1586, 332. Photo: Melissa Rickman, with courtesy University of Oklahoma History of Science Collections). an astronomical anti-astrology book at Ljubljana. Urbas published his German and Slovene atomistic physics for Carniolan intellectual circles attributing individual life to each atom (Urbas 1876, 2). Not recognizing three years earlier published Maxwell's theory Urbas considered heat flow much slower compared to light velocity (Urbas $1876,23)$. The subterranean was still a puzzle and Urbas described the raise of heat during earthquakes (Ur- bas 1876, 24). As his older Celovec contemporary Karl Robida, Urbas believed at the vibrations of ether (Urbas $1876,25)$. As one of the leading intellectuals of his time Ljubljana Urbas was certainly the right person to translate Cerknica Lake poetry three centuries after Frischlin wrote it.

\section{CONCLUSION}

The special circumstances of Protestant international collaboration brought to the Inner Austrian capitals the very best Tübingen scientists: Frischlin to Ljubljana, Frischlin best student as well as the first Slovene lexicographer Megiser to Celovec, and Kepler to Graz. Tübingen did not just provide Ljubljana with Trubar's circle Protes- tant Slovene literature, but also with the brand new ideas which penetrated even into the karst subterranean. Tübingen's Protestant influence brought fruits to the next generations although Frischlin's contributions were far less known until now. 


\section{ACKNOWLEDGEMENTS}

We wish to express our gratitude to the Mellon fellowship of the Oklahoma University History of Science Department.

\section{ABBREVIATIONS}

\section{REFERENCES}

Elze, T., 1877: Die Universität Tübingen und die Studenten aus Krain.- Fues, p. 109, Tübingen. Reprint: 1977: Trofenik, p. 142, München.

Elze, T., 1899: Die Rektoren der krainischen Landschaftlschule in Laibach währen des XVI. Jahrhunderts.- Jahrbuch der Gesellschaft für die Geschicghte des Protestantismus in Oesterreich (Klinckhard, Wien/ Manz/ Leipzig), 12, 3-4, 117-153.

Frischlin, N., 1575: Carmen de Astronomico Holorogio Argentoratensi.- Wyriot, Argentorati (Strasbourg).

Frischlin, N., 1580: Oratio de vita rustica.- Alexander Hock, Tübingen.

Frischlin, N., 1586: De astronomicae artis, cum doctrina coelesti, et naturali philosophia, congruentia, ex optimis quibusque Graecis Latinisque scriptoribus, theologis, medicis, mathematicis, philosophis \& poëtis collecta: libri quinque. Passim insterta est huic operi solida divinationum astrologicarum confutatio, repetita ex optimis quibusq(ue) auctoribus, tam recentibus quam veteribus, quorum nomina post praefationem inuenies.- Spieß, p. 469, Francoforti ad Moenum. Reprint: 1601: - Richter; Spieß, Francoforti.

Froeschlin, E., 1979: Ein Unbehäb Maul wider die Obrigkeit: Leben und Wirken des Dichters Nicodemus Frischlin.- Schwäbische Verlagsgesellschaft, Tübingen.

Gams, I., 2003: Kras v Sloveniji v prostoru in času.- ZRC SAZU, p. 516, Ljubljana.

Granada, M.A., 2007: Michael Maestlin and the New Star of 1572.- Journal for the History of Astronomy, $38,99-124$.
Gruber, T., 1795: Von den Vortheilen hydrographischen Karten.- Neuere Abhandlungen der k. böhmischen Gesellschaft der Wissenschaften. 1789-1791. Degen, Wien und Prag, 2, 2, 3-17.

Habe, F. \& A. Kranjc, 1981: Delež Slovencev v speleologiji.- Zbornik za zgodovino naravoslovja in tehnike, 5-6, 13-93, Ljubljana.

Hermelink, H. (Ed.), 1976: Die Matrikeln der Universität Tübingen.- Kraus Reprint, Nendeln/Liechtenstein.

Janko, A., 1996: Nemško literarno tvorstvo na Slovenskem v 16. stoletju.- In: Jakopin, F., Kerševan, M., Pogačnik, J. (Eds.), III Trubarjev zbornik. Slovenska Matica, Ljubljana, 168-177.

Južnič, S., 2007a: Books about karst and subterranean in Auersperg" Princes's" Library of Ljubljana.- Acta carsologica, 36, 2, 305-314, Ljubljana.

Južnič, S., 2007b: Subterranean waters described in Carniolan letters mailed to A. Kircher $\left({ }^{\star} 1601 ;+1680\right)$.Acta carsologica, 36, 3, 503-510, Ljubljana.

Kidrič, F., 1925-1932: Frischlin Nicodem.- SBL, 1, 190192. Zadružna gospodarska banka, Ljubljana.

Methuen, C., 1998: Kepler's Tübingen: Stimulus to a theological mathematics.- Ashgate, Aldershot.

Poggendorff, J.C., 1863-1898: Biographisch-Literarisches Hadwörterbuch zur Geschichte der exacten Wissenschaften von J.C. Poggendorff-- Johann Ambrosius Barth, 1-2. Leipzig. Reprint: 1965: Israël, Amsterdam.

Reisp, B., 1983: Janez Vajkard Valvasor.- Mladinska knjiga, Ljubljana.

Röckelein, H. \& C. Bumiller, 1990: Nikodemus Frischlin: ein unruhig Poet 1547-1590.- Veröffentlichungen des Stadtarchivs, Balingen. 
Savnik, R., 1982: Urbas Anton.- SBL, 4, 302-303.

Schmidl, A., 1850: Notizen über den von ihm under der Planina-Höhle mitgebrachten und der Classe vorgezeigten Proteen.- Wien. Ber. Mat. Nat. Cl., 5, 3, 228-232, Vienna.

Strauss, D.F., 1856: Leben und Schriften des Dichters und Philologen Nicodemus Frischlin.- Literarische Anstalt, Frankfurt am Main.

Thorndike, L., 1941-1958: History of Magic and Experimental Science.- Columbia University Press, New York.

Urbas, A., 1849: Die Grotten und Abgründe bei Planina.Illyrische Blätt., 32, 34, 37, Ljubljana.

Urbas, A., 1876: Magnetismus, Elektricität, Wärme und Licht (Magnetizem, elektrika, toplota in svetloba. Filozofično-fizikaličen načrt.- Samozaložba v tisku J. Blasnikovih dedičev, Laibach/Ljubljana.
Urbas, W., 1879: Das Phänomen des Zirknitzer Sees und die Karstthäler von Krain.- Zeitschrift des deutschen und österreischischen Alpenvereines, 17-25, Wien.

Valvasor, J.V., 1689: Die Ehre dess Hertzogthums Crain.Wolfgang Moritz Endter, p. 696, 836, 730, 610, Laybach-Nürnberg. Reprint: 1971: - Trofenik, 1-4, München. Partial translation: 1977: - Mladinska knjiga, Ljubljana.

Vidmar, T., 2000: „Obena deshela, ne meistu ne gmaina, ne mogo pres shul« - Usoda protestantskih deželnih šol v Ljubljani, Celovcu in Gradcu.- Šolska kronika, 9, 33, 1, 9-27, Ljubljana.

Werner, G., 1551: Hypomnematio de Admirandis Hungariae aquis.- Viennae.

Weichenhan, M., 2004: "Ergo perit coelum... “: Die Supernova des Jahres 1572 und die überwindung der aristitelischen Kosmologie.- Franz Steiner, Stuttgart.

\section{FRISCHLIN O KRAŠKIH POJAVIH CERKNIŠKEGA JEZERA}

\section{POVZETEK}

Ljubljanski rektor Frischlin je opeval Cerkniško jezero v eni najlepših latinskih pesnitev sestavljenih na slovenskih tleh. Ob tem je Frischlin v Ljubljani sestavil celo vplivno astronomsko delo, najbolj zgodnjo knjigo tako visoke ravni nastalo $\mathrm{v}$ naših krajih. Frischlinovi znanstveni prispevki postajajo danes predmet številnih raziskav $\mathrm{v}$ povezavi s Keplerjevim študijem v Tübingenu. Seveda pa se same po sebi odpirajo tudi Frischlinove povezave s Trubarjevim tübingenskim krogom, ki je Frischlinu omogočil prihod v Ljubljano, čeravno ni vedno podpiral Frischlinovega dela in tudi ne raziskovanja krasa.

$\mathrm{V}$ tem sestavku je prvič v zgodovinopisju izpostavljena razmeroma obsežna Valvasorjeva predstavitev Frischlinovega ljubljanskega rektorata s poudarkom na njegovi pesnitvi v slavo čudesom Cerkniškega jezera. Valvasor se je vsekakor zavedal pomena Frischlinovih raziskav krasa in jih je vtkal v svojo lastno teorijo, ki mu je prinesla uspeh v Londonu. Kljub temu je Frischlinovo raziskovanje krasa za dve stoletji utonilo v pozabo tudi zato, ker je latinski pesniški jezik kmalu postal nedostopen novim generacijam učenjakov. Seveda ne vsem, saj je teologom latinščina ostala osnovni jezik delovanja. Tako ne preseneča, da je Frischlinovo odo našemu krasu in še posebej Cerkniškemu jezeru delno prevedel ravno duhovnik Anton Urbas, ki je bil obenem tudi prvovrsten jamar na Notranjskem. Frischlinovo delo v našem šolstvu in kulturi je znano in raziskano; to pot pa je prvič predstavljen tudi kot krasoslovec. 
